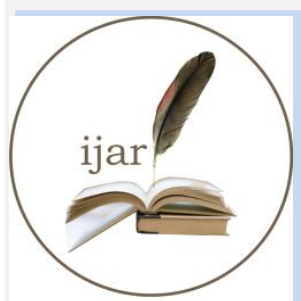

ISSN NO. 2320-5407

\section{Journal Homepage: - www.journalijar.com INTERNATIONAL JOURNAL OF ADVANCED RESEARCH (IJAR)}

Article DOI: $10.21474 / \mathrm{IJAR01/1340}$

DOI URL: http://dx.doi.org/10.21474/IJAR01/1340
INTERNATIONAL JOURNAL OF ADVANCED RESEARCH (JJAR)

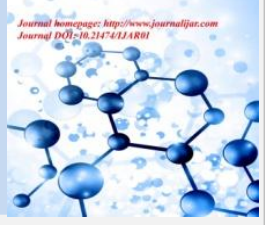

RESEARCH ARTICLE

\title{
FORMULATION AND EVALUATION OF AZILSARTAN KAMEDOXOMIL FAST DISSOLVING TABLETS.
}

"Mohamed A. Kassem, Magdy I. Mohamed and Asmaa A. Mohamed. Department of Pharmaceutics and Industrial Pharmacy, Faculty of Pharmacy, Cairo University, Cairo, Egypt.

\section{Manuscript Info}

Manuscript History

Received: 12 June 2016

Final Accepted: 19 July 2016

Published: August 2016

Key words:-

Azilsartan kamedoxomil, fast dissolving tablets, sublimation, effervescent approaches.

\begin{abstract}
The purpose of this work was to formulate and prepare fast dissolving tablets of azilsartan kamedoxomil which is practically insoluble drug for improving its poor oral bioavailability and with the aim of alleviating administration to patients facing problems with swallowing. Tablets were prepared adopting effervescent and sublimation techniques. Ac-Di-Sol, explotab, crospovidone and glycine were used as superdisintigrants along with blend of sodium bicarbonate, citric acid (as effervescent mixture) and menthol and ammonium carbonate (as sublimating agents). The mixture was directly compressed using Avicel PH 102, Sorbitab and lactose fast flow as diluent. Pre-compression parameters such as bulk density, tapped density, bulkiness, compressibility (Carr's index), Hausner ratio and angle of repose were evaluated. Post-compression parameters such as weight variation, content uniformity, hardness, friability, disintegration time, in-vitro dispersion time, wetting time, water absorption ratio and in vitro dissolution were performed and compared to commercially product Edarbi ${ }^{\circledR} 40 \mathrm{mg}$ tablets. Results revealed that SD2, SD3, SD4, EF4 and EF6 could increase amount of azilsartan kamedoxomil dissolved to more than $80 \%$ within $10 \mathrm{~min}$. Stability studies were performed on the selected formulae namely; $\mathrm{SD} 2, \mathrm{SD} 3, \mathrm{SD} 4, \mathrm{EF} 4, \mathrm{EF} 6$ and Edarbi $^{\circledR} 40 \mathrm{mg}$ tablets. The physicochemical properties of stored tablets were performed
\end{abstract}

Copy Right, IJAR, 2016,. All rights reserved.

\section{Introduction:-}

Fast dissolving tablets are the dosage forms that dissolve or disintegrate in oral cavity within a minute, and significantly increases the bioavailability than those observed from the conventional tablets. Several approaches have been employed to formulate fast dissolving tablets involving tablet molding, freeze drying, sublimation, effervescent approach, spray drying, disintegrant addition-direct compression and use of sugar based excipients. Disintegrant addition-direct compression is a well known technique where disintegrants help to facilitate drug dissolution and consequently improve the bioavailability. Disintegrants that are effective at lower levels and help in rapid disintegration are of great importance in formulations by direct compression. Soluble effervescent tablets dissolve quickly and can be easily consumed by patients. A high porosity can be achieved using menthol and

Corresponding Author:- Mohamed A. Kassem.

Address:- Department of Pharmaceutics and Industrial Pharmacy, Faculty of Pharmacy, Cairo University, Cairo, Egypt. 
ammonium carbonate as volatilizing agent allowing easy penetration of dissolution media to tablet matrix followed by rapid drug release.

Azilsartan kamedoxomil (AZM) is designated chemically as (5-Methyl-2-oxo-1, 3-dioxol-4-yl) methyl 2-ethoxy-1\{[2'-(5-oxo-4,5-dihydro-1,2,4-oxadiazol-3-yl)biphenyl-4-yl]methyl $\}-1 \mathrm{H}$-benzimidazole carboxylate monopotassium salt. The active moiety is revealed by hydrolysis of the medoxomil ester. It has molecular formula $\mathrm{C}_{30} \mathrm{H}_{23} \mathrm{KN}_{4} \mathrm{O}_{8}$, molecular weight $606.62^{(1)}$ and it has the following structural formula (Fig.1)

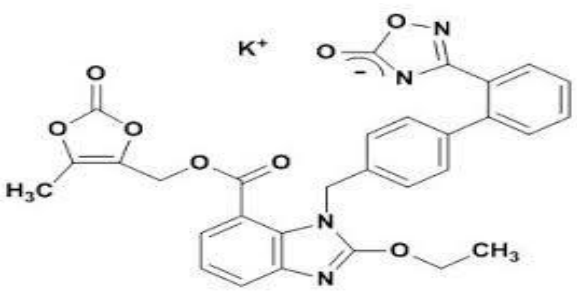

Fig.1:- chemical structure of Azilsartan kamedoxomil

Azilsartan medoxomil selectively inhibits angiotensin II from binding to the angiotensin II type-1 receptor (AT1). This receptor inhibition provides the antihypertensive activity of azilsartan medoxomil because it blocks the pressor effects of angiotensin II. Azilsartan medoxomil is a prodrug, it is hydrolyzed to the active moiety, azilsartan, in the gastrointestinal tract during the absorption phase. The estimated absolute bioavailability of azilsartan is $60 \%$. Absorption is not affected by food, and peak plasma concentrations are reached within 1.5 to 3 hours. ${ }^{(1-3)}$

\section{Materials and methods:-}

Materials:- Azilsartan kamedoxomil (AZM) was purchased from Virdev, India, Explotab, Avicel PH 102, Crospovidone, menthol, ammonium carbonate, monosodium fumarate, glycine, sorbitab, citric acid, sodium citrate, Ac-di-sol, lactose fast flow, aspartame and magnesium stearate; Elkahira Pharma. Chem., Shoubra, Cairo, Egypt. Methanol for HPLC, acetonitrile for HPLC; E. Merck, Darmstadt, Germany, hydrochloric acid, ammonium acetate; El-Nasr Pharma. Chem., Cairo, Egypt. High purity water was prepared by using Waters Milli-Q plus purification system.

\section{Methodology:-}

Validated developed HPLC stability indicating assay:-

A kromasil@, C18 $(5 \mu \mathrm{m}, 25 \mathrm{~cm} \times 4.6 \mathrm{~mm})$ column, waters HPLC apparatus consisting of: pump 1525 and a UV/VIS detector 2487. The injection volume was $50 \mu \mathrm{l}$ and a mobile phase consisting of M ammonium acetate (pH: 2.5): acetonitrile $(40: 60 \mathrm{v} / \mathrm{v} / \mathrm{v})$, a flow-rate of $2.0 \mathrm{ml} . \mathrm{min}^{-1}$ at $254 \mathrm{~nm}$. Linearity range was $10.0-70.0 \mu \mathrm{g} . \mathrm{ml}^{-1}$.

\section{Preparation of tablets via sublimation approach:-}

Azilsartan kamedoxomil, Avicel PH 102 or Sorbitab or lactose fast flow as diluent, explotab or crospovidone and/or Ac-Di-sol or glycine as disintegrant, monosodium fumarate or citric acid/ sodium citrate as buffering agents, ammonium carbonate or menthol as effervescent ingredients, aspartame as sweating agent were sieved through $600 \mu \mathrm{m}$ sieve and mixed. Finally, lubricant (magnesium stearate) was sieved through $600 \mu \mathrm{m}$ sieve and mixed with the previous powder. Tablets were compressed on flat punch $8 \mathrm{~mm}$ then dried at vaccum oven at $60^{\circ} \mathrm{C}$ for $24 \mathrm{hr}$. (Table 1)

\section{Preparation of tablets via effervescent approach:-}

Azilsartan kamedoxomil, Avicel PH 102 or Sorbitab or lactose fast flow as diluent, explotab or crospovidone and/or Ac-Di-sol or glycine as disintegrant, citric acid and sodium bicarbonate as effervescent ingredients, aspartame as sweating agent were sieved through $600 \mu \mathrm{m}$ sieve and mixed. Finally, lubricant (magnesium stearate) was sieved through $600 \mu \mathrm{m}$ sieve and mixed with the previous powder blend. Tablets were compressed on flat punch $8 \mathrm{~mm}$. All tablets were compressed into 180-mg using a single punch tablet machine [Erweka, Germany] of about 3-7 $\mathrm{kg}$ hardness. The force of compression was kept constant throughout the compression process (Table 2) 


\section{Evaluation of pre-compression parameters:-}

Bulk density:

Bulk density was defined as the mass of the powder divided by the bulk volume ${ }^{(4)}$ and is expressed as $\mathrm{g} / \mathrm{cm} 3$ :

Bulk density $=$ mass of powder/bulk volume of powder .

\section{Tapped density:}

Powder blend was taken and filled into $10 \mathrm{~mL}$ measuring cylinder which was tapped until the constant height was obtained $^{(5)}$. Tapped density $=$ mass of powder/volume of powder after tapping.

\section{Bulkiness:}

Specific bulk volume or reciprocal of bulk density is called as bulkiness or bulk. The bulkiness was calculated by the following formula ${ }^{(6)}$ :

Bulkiness $=1 / \mathrm{b} \quad$ where, $\mathrm{b}$ is the bulk density.

\section{Compressibility (Carr's index):}

Compressibility was determined from the equation: Carr's index $=(1-\mathrm{Vt} / \mathrm{Vb}) \times 100^{(7)}$

\section{Hausner ratio:}

Hausner ratio was obtained by dividing $\mathrm{V}_{\mathrm{b}}$ by $\mathrm{V}_{\mathrm{t}}{ }^{(8)}$

Where $\mathrm{V}_{\mathrm{t}}$ is the tapped volume and $\mathrm{V}_{\mathrm{b}}$ is the bulk volume

\section{Angle of repose:}

Fixed height cone method was used ${ }^{(9)}$. The angle of repose $(\theta)$ was calculated from the equation: $\tan \theta=2 \mathrm{~h} / \mathrm{D}$.

\section{Evaluation of post compression properties:}

\section{Weight variation:}

Twenty tablets, from each formula, were individually weighed [Sartorius, Gottingen, Germany]. The mean weight of tablets was calculated. ${ }^{(10)}$

\section{Content uniformity:}

The uniformity of content was determined by crushing ten tablets from each formula and determining the drug content of each tablet individually using the developed method HPLC. ${ }^{(10)}$

\section{Friability:}

Ten tablets from each formula were accurately weighed and placed in the drum of a friablator [Pharma Test, Germany], which rotated at 25 r.p.m. for a period of 4 minutes. The tablets were then brushed and reweighed. The percentage loss in weights was calculated and taken as a measure of friability ${ }^{(10)}$

\section{Hardness:}

Ten tablets from each formula were tested for their hardness [Tablet Hardness Tester, Erweka, Germany]. The mean hardness in kilograms was then determined. ${ }^{(10)}$

\section{Disintegration time:}

The disintegration time for each of six tablets from each formula was determined using USP Disintegration Tester [USP Disintegration, Pharma Test, Germany]. ${ }^{(11)}$

\section{In-vitro dispersion time test:}

Ten $\mathrm{ml}$ measuring cylinder was taken in which $6 \mathrm{ml}$ distilled water was added then a tablet was dropped in it. The time for the tablet to completely disintegrate into fine particles was noted. Three tablets from each formulation were tested and results were expressed in seconds ${ }^{(12)}$.

\section{Wetting time ${ }^{(13)}$ :}

Five circular tissue papers of $10 \mathrm{~cm}$ diameter were placed in a Petri dish with a $10 \mathrm{~cm}$ diameter. Ten millimeters of water-containing Eosin, a water-soluble dye were added to petridish. A tablet was carefully placed on the surface of the tissue paper. The time required for water to reach uppermost surface of the tablet was noted. 


\section{Water absorption ratio:}

A piece of tissue paper was folded twice and placed in a small Petridish containing $6 \mathrm{ml}$ of water. A tablet was put on the paper. The wetted tablet was then weighed. Water absorption ratio (R), was calculated as $\mathbf{R}=\mathbf{1 0}(\mathbf{W a} / \mathbf{W b})$

Where: $\mathrm{Wb}$ is the weight of tablet before water absorption and $\mathrm{Wa}$ is the weight of tablet after water absorption. ${ }^{(14)}$.

\section{In-vitro dissolution studies:}

The test was performed in phosphate buffer $\mathrm{pH} 7.8$ at a temperature of $37 \pm 0.5^{\circ} \mathrm{C}$ using the USP Dissolution Tester [Dissolution Apparatus Validata SR 6, Hanson Research Corporation, USA] at a temperature of $37 \pm 0.5^{\circ} \mathrm{C}$. Apparatus II (paddle), at a rotation of 50. The samples were analyzed by HPLC as mentioned above.

\section{Accelerated stability testing of azilsartan kamedoxomil tablets:}

The selected tablets formulae were stored in transparent and opaque strips at $25^{\circ} \mathrm{C} \pm 2{ }^{\circ} \mathrm{C} / 60 \% \pm 5 \% \mathrm{RH}$ for twelve months [Angelatoni Stability Chamber, Italy], and $30^{\circ} \mathrm{C} \pm 2{ }^{\circ} \mathrm{C} / 65 \% \pm 5 \% \mathrm{RH}$ for six months [Hotpak Stability Chamber, USA] and $40^{\circ} \mathrm{C} \pm 2^{\circ} \mathrm{C} / 75 \% \pm 5 \% \mathrm{RH}$ for six months [Climacel Stability Chamber, Germany]. The stored tablets were examined visually for any changes in colour and/or appearance and analyzed chemically by HPLC.

Table 1:- Formulae* of the rapidly dissolving tablets prepared by sublimation method:

\begin{tabular}{|c|c|c|c|c|c|c|c|c|c|c|c|c|}
\hline \multirow[b]{2}{*}{$\begin{array}{l}\frac{\pi}{5} \\
\text { ह } \\
\text { 오 }\end{array}$} & \multicolumn{3}{|c|}{ Diluent } & \multicolumn{4}{|c|}{ Disintegrant } & \multicolumn{2}{|c|}{ Sublimating agent } & \multicolumn{3}{|c|}{ Buffering agent } \\
\hline & 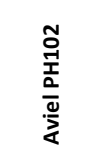 & 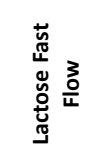 & 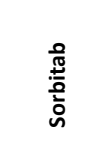 & 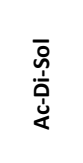 & $\begin{array}{l}\frac{0}{\mathbb{J}} \\
\frac{0}{0} \\
\frac{0}{x}\end{array}$ & 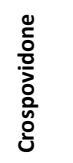 & $\frac{\stackrel{0}{\frac{V}{U}}}{\mathbb{V}}$ & 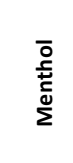 & 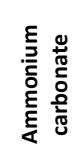 & 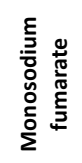 & 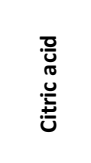 & 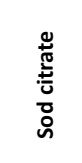 \\
\hline SD1 & ------ & 104.322 & ------ & 15 & ---- & ----- & ---- & ----- & 10 & ------ & -------- & ------- \\
\hline SD 2 & ----- & 59.32 & |------ & ----- & |---- & 50 & |---- & |---- & 10 & 10 & |------- & |------ \\
\hline SD 3 & |----- & 51.62 & |---- & |---- & ----- & 60 & ---- & 10 & |------ & ----- & 5 & 2.7 \\
\hline SD 4 & ---- & 46.62 & ---- & ----- & --- & 50 & ---- & ----- & ------ & ------ & 5 & 2.7 \\
\hline SD 5 & ---- & ----- & 104.322 & 15 & ----- & ----- & ---- & ----- & 10 & ------- & ----- & ------ \\
\hline SD 6 & ------ & ------ & 96.62 & ---- & 15 & ----- & ---- & 10 & ------ & ------ & 5 & 2.7 \\
\hline SD 8 & ---- & ---- & 46.62 & 15 & ----- & 50 & ---- & ----- & 10 & ---- & 5 & 2.7 \\
\hline SD 9 & 104.32 & ------ & ------ & ------ & 15 & --- & ----- & ----- & 10 & ----- & ----- & ----- \\
\hline SD 10 & 59.32 & ------ & ------ & |------ & ------ & 50 & ---- & 10 & ----- & ------ & 5 & 2.7 \\
\hline SD 11 & 34.32 & & & ------ & --- & 50 & ----- & 10 & ------ & ------ & ------ & ------" \\
\hline SD 12 & 71.62 & & & ----- & & ----- & 40 & ----- & 10 & ----- & 5 & 2.7 \\
\hline
\end{tabular}

*Each formula contains 42.68mg azilsartan kamedoxomil, 5mg aspartame and 3mg magnesium stearate 


\begin{tabular}{|c|c|c|c|c|c|c|c|c|}
\hline \multirow[b]{2}{*}{ Formula } & \multicolumn{3}{|c|}{ Diluent } & \multicolumn{3}{|c|}{ Disintegrant } & \multicolumn{2}{|c|}{ Effervescent agent } \\
\hline & 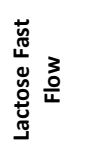 & $\begin{array}{l}\frac{0}{0} \\
\frac{1}{0} \\
\text { 은 } \\
\text { ம }\end{array}$ & 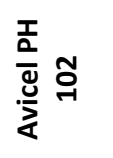 & $\begin{array}{l}\overline{0} \\
\dot{1} \\
\dot{0} \\
\dot{d}\end{array}$ & $\begin{array}{l}\frac{0}{\pi} \\
\frac{0}{0} \\
\frac{0}{x}\end{array}$ & $\begin{array}{l}0 \\
\frac{0}{0} \\
\frac{0}{0} \\
\frac{0}{0} \\
\stackrel{0}{0}\end{array}$ & 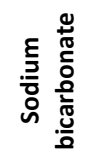 & 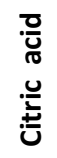 \\
\hline EF 1 & ------- & ------- & 94.32 & 15 & ----- & +---- & 10 & 10 \\
\hline EF 2 & ------- & ------- & 104.32 & ----- & 15 & --- & 5 & 5 \\
\hline EF 3 & ----- & ----- & 54.34 & 15 & $-\cdots$ & --- & 10 & 10 \\
\hline EF 4 & 47.32 & ---- & ---- & 15 & --- & ---- & 12 & 15 \\
\hline EF 5 & 49.32 & ------ & ----- & ---- & ----- & 50 & 15 & 15 \\
\hline EF 6 & 19.32 & ------ & ----- & 15 & ---- & 50 & 20 & 25 \\
\hline EF 7 & +---- & 84.32 & $-\cdots$ & 15 & ----- & ---- & 15 & 15 \\
\hline EF 8 & --- & 84.32 & ----- & ---- & 15 & ---- & 15 & 15 \\
\hline EF 9 & ----- & 34.32 & ----- & 15 & ------ & 50 & 15 & 15 \\
\hline EF 10 & ----- & 34.32 & +---- & ---- & 15 & 50 & 15 & 15 \\
\hline
\end{tabular}

*Each formula contains 42.68mg azilsartan kamedoxomil, 5mg aspartame and 3mg magnesium stearate

Effect of storage on the properties of azilsartan kamedoxomil tablets:-

Evaluation of the tablets hardness, and dissolution were utilized after storage at $40^{\circ} \mathrm{C} /$ relative humidity of $75 \%$ [Climacel Stability Chamber, Germany]. Similarity factor (f2) was used to compare the data.

$$
f_{2}=50 \times \log \left\{\left[1+(1 / n) \Sigma t=1 n\left(R_{t}-T_{t}\right) 2\right]^{-0.5} \times 100\right\}
$$

Where $\mathrm{n}$ is the number of time points, $\mathrm{R}$ is the dissolution value of the reference at time $\mathrm{t}$, and $\mathrm{T}$ is the dissolution value of the test at time $\mathrm{t}^{(15,16)}$.

Determination of The expiration dates:-

The expiration dates of the selected formulae were determined by extrapolation of Arrhenius curve. It is the time at which the percent drug remaining is $90 \%$

\section{Results and discussion:-}

Evaluation of pre-compression parameters were shown in Table 3. All the batches showed the values of angle of repose ranged from $24.81^{\circ}$ to $31.5^{\circ}$ indicating good flow properties while angle repose of azilsartan kamedoxomil alone was $43^{\circ}$. Hauser's ratio ranged between 1.145 - 1.186 while Hauser's ratio of azilsartan kamedoxomil alone was 1.35 and the compressibility of powder mixture was within the range of $11.71 \%$ to $15.73 \%$ indicating that all the formulations showed good compressibility while compressibility of azilsartan kamedoxomil alone was $26.19 \%$. Bulkiness was found to be in the range of 1.78 to 1.91 while bulkiness of azilsartan kamedoxomil alone was 2.22.

Formulation s post compression properties were shown in Table 4. All Formulations were evaluated for weight variation and results indicated very low weight variation which lies within pharmacopeial limits i.e $\pm 7.5 \%$. Hardness was seen to be in the range of values of 4.3 to $6.9 \mathrm{~kg}$., friability of all formulae was less than $1 \%$, disintegration time of formulae tablets was in the range of 26 to $65 \mathrm{sec}$., while disintegration time of Edarbi® 40 mg tablets was 210 sec. In vitro dispersion time was in the range of 55 to $141 \mathrm{sec}$. Wetting time was in the range of 6.05 to $11.36 \mathrm{sec}$. Water absorption ratio was in the range of $85 \%$ to $120 \%$ 
Table 3:- Pre-compression properties of the chosen formulations

\begin{tabular}{|c|c|c|c|c|c|c|}
\hline Formula & $\begin{array}{l}\text { Bulk } \\
\text { density }\end{array}$ & $\begin{array}{l}\text { Tapped } \\
\text { density }\end{array}$ & $\begin{array}{l}\text { Hausner } \\
\text { ratio }\end{array}$ & $\begin{array}{l}\text { Carr's } \\
\text { index }\end{array}$ & Bulkiness & $\begin{array}{l}\text { Angle of repose } \\
(\theta)\end{array}$ \\
\hline $\begin{array}{l}\text { Azilsartan } \\
\text { kamedoxomil }\end{array}$ & $0.451 \pm 0.023$ & $0.611 \pm 0.013$ & $1.35 \pm 0.018$ & $26.19 \pm 0.014$ & $2.22 \pm 0.015$ & $43.00 \pm 1.2$ \\
\hline SD1 & $0.542 \pm 0.047$ & $0.621 \pm 0.029$ & $1.145 \pm 0.046$ & $12.72 \pm 0.034$ & $1.84 \pm 0.025$ & $29.62 \pm 1.5$ \\
\hline SD 2 & $0.535 \pm 0.051$ & $0.616 \pm 0.051$ & $1.151 \pm 0.034$ & $13.15 \pm 0.046$ & $1.87 \pm 0.019$ & $28.16 \pm 1.10$ \\
\hline SD 3 & $0.533 \pm 0.054$ & $0.620 \pm 0.22$ & $1.163 \pm 0.042$ & $14.03 \pm 0.064$ & $1.88 \pm 0.013$ & $30.07 \pm 1.14$ \\
\hline $\mathrm{SD} 4$ & $0.540 \pm 0.039$ & $0.622 \pm 0.045$ & $1.151 \pm 0.051$ & $14.41 \pm 0.079$ & $1.85 \pm 0.013$ & $29.72 \pm 0.9$ \\
\hline SD 5 & $0.539 \pm 0.051$ & $0.639 \pm 0.056$ & $1.186 \pm 0.043$ & $15.65 \pm 0.112$ & $1.85 \pm 0.025$ & $28.67 \pm 1.1$ \\
\hline SD 6 & $0.551 \pm 0.014$ & $0.639 \pm 0.042$ & $1.145 \pm 0.108$ & $11.71 \pm 0.347$ & $1.81 \pm 0.021$ & $29.56 \pm 0.8$ \\
\hline SD 7 & $0.545 \pm 0.029$ & $0.624 \pm 0.043$ & $1.145 \pm 0.099$ & $12.66 \pm 0.267$ & $1.83 \pm 0.023$ & $30.37 \pm 1.7$ \\
\hline SD 8 & $0.539 \pm 0.041$ & $0.626 \pm 0.029$ & $1.161 \pm 0.096$ & $13.90 \pm 0.178$ & $1.85 \pm 0.034$ & $29.83 \pm 1.2$ \\
\hline SD 9 & $0.535 \pm 0.036$ & $0.624 \pm 0.039$ & $1.166 \pm 0.091$ & $13.64 \pm 0.218$ & $1.87 \pm 0.035$ & $30.92 \pm 0.8$ \\
\hline SD 10 & $0.531 \pm 0.026$ & $0.630 \pm 0.026$ & $1.186 \pm 0.290$ & $15.73 \pm 0.523$ & $1.88 \pm 0.035$ & $31.50 \pm 1.2$ \\
\hline SD 11 & $0.562 \pm 0.063$ & $0.649 \pm 0.047$ & $1.156 \pm 0.161$ & $13.48 \pm 0.308$ & $1.78 \pm 0.035$ & $28.51 \pm 0.26$ \\
\hline SD 12 & $0.568 \pm 0.036$ & $0.658 \pm 0.039$ & $1.158 \pm 0.099$ & $13.64 \pm 0.218$ & $1.76 \pm 0.035$ & $28.13 \pm 0.37$ \\
\hline EF-1 & $0.531 \pm 0.054$ & $0.611 \pm 0.025$ & $1.151 \pm 0.047$ & $13.093 \pm 0.127$ & $1.88 \pm 0.053$ & $26.52 \pm 1.1$ \\
\hline EF-2 & $0.525 \pm 0.031$ & $0.606 \pm 0.036$ & $1.154 \pm 0.053$ & $13.366 \pm 0.138$ & $1.91 \pm 0.061$ & $27.32 \pm 0.8$ \\
\hline EF-3 & $0.533 \pm 0.047$ & $0.627 \pm 0.041$ & $1.176 \pm 0.040$ & $14.992 \pm 0.029$ & $1.88 \pm 0.043$ & $28.49 \pm 1.2$ \\
\hline EF-4 & $0.539 \pm 0.025$ & $0.622 \pm 0.034$ & $1.154 \pm 0.031$ & $13.344 \pm 0.026$ & $1.85 \pm 0.015$ & $27.42 \pm 0.8$ \\
\hline EF-5 & $0.549 \pm 0.046$ & $0.629 \pm 0.027$ & $1.146 \pm 0.024$ & $12.718 \pm 0.053$ & $1.82 \pm 0.028$ & $24.81 \pm 0.7$ \\
\hline EF-6 & $0.531 \pm 0.053$ & $0.619 \pm 0.035$ & $1.166 \pm 0.033$ & $14.216 \pm 0.094$ & $1.88 \pm 0.031$ & $28.70 \pm 1.1$ \\
\hline EF-7 & $0.545 \pm 0.047$ & $0.634 \pm 0.042$ & $1.163 \pm 0.013$ & $14.038 \pm 0.096$ & $1.83 \pm 0.042$ & $27.36 \pm 1.2$ \\
\hline $\mathrm{EF}-8$ & $0.539 \pm 0.041$ & $0.626 \pm 0.021$ & $1.161 \pm 0.034$ & $13.898 \pm 0.153$ & $1.86 \pm 0.061$ & $27.61 \pm 0.9$ \\
\hline EF-9 & $0.535 \pm 0.026$ & $0.624 \pm 0.030$ & $1.166 \pm 0.053$ & $14.263 \pm 0.164$ & $1.87 \pm 0.016$ & $27.46 \pm 1.1$ \\
\hline EF-10 & $0.561 \pm 0.045$ & $0.611 \pm 0.025$ & $1.164 \pm 0.024$ & $14.089 \pm 0.098$ & $1.78 \pm 0.024$ & $28.19 \pm 0.8$ \\
\hline
\end{tabular}

In vitro release of azilsartan kamedoxomil from the prepared tablets (formulae SD2, SD3, SD4), showed that more than $80 \%$ of the drug was released after 10 min $\left(Q_{10}\right)$, these results were attributed to the behaviour of sublimating agent after compression which increased porosity of the formed tablets ${ }^{(17)}$. This increases the solubility of azilsartan medoxomil and the release was superior to that of azilsartan kamedoxomil from Edarbi® 40 tablets which showed $65 \%$ after 10 min. Formulae prepared adopting effervescent approach exhibited dissolution of more than $75 \%$ of azilsartan kamedoxomil after 10 min while EF4, EF6 released more than $85 \%$ of the drug after 10 min. The formulae SD2, SD3, SD4, EF4 and EF6 were selected because of the highest release and acceptable disintegration time.dissolution results from the different formulae are presented in Fig. 2. 


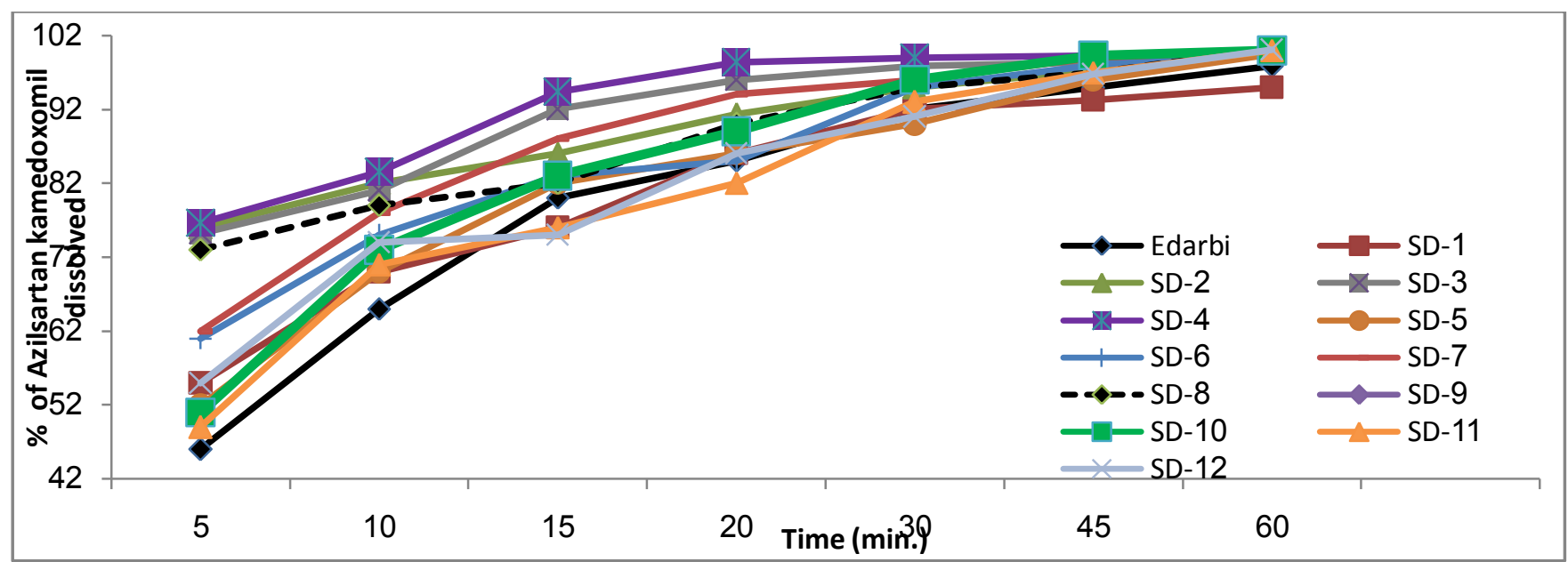

Fig.2:- Dissolution of SD1-SD12 compared to Edarbi® tablets at pH 7.8 .

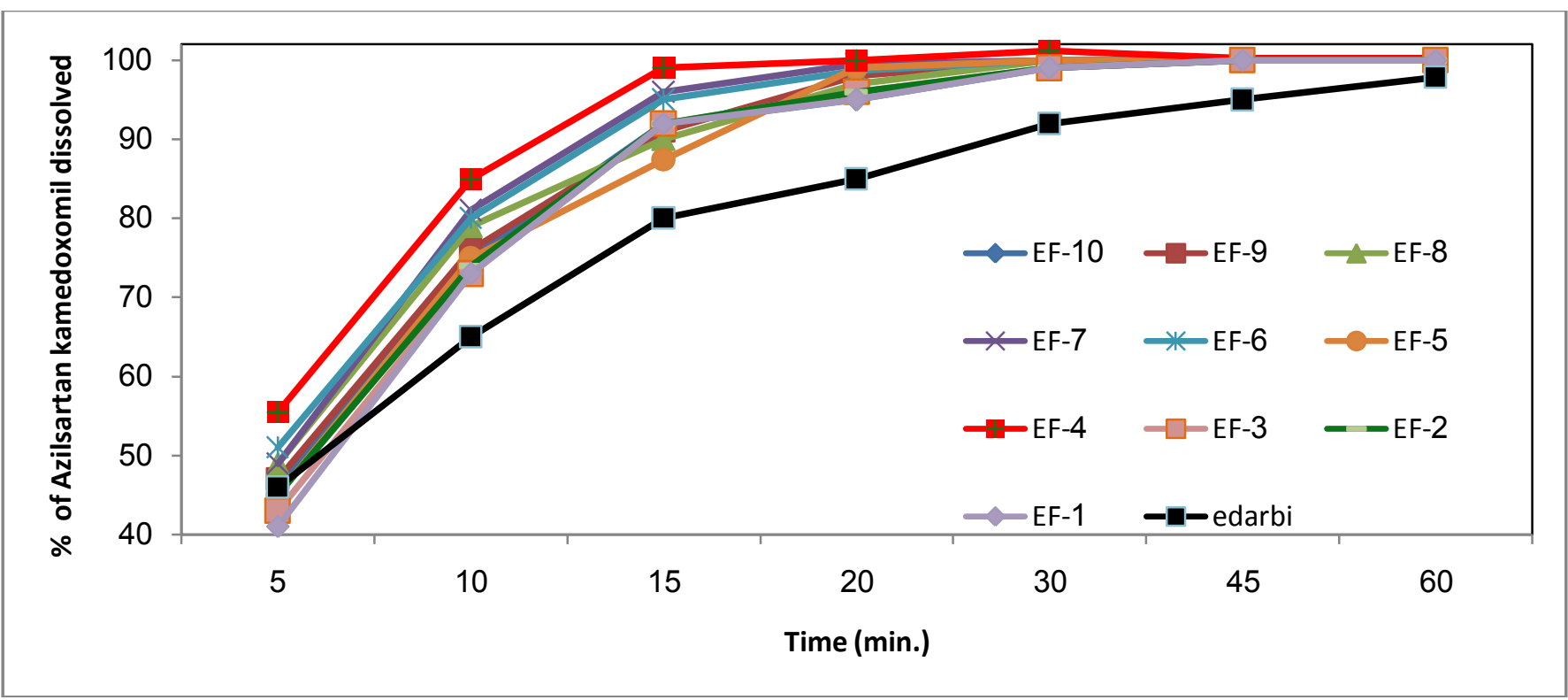

Fig.3:- Dissolution of EF1-EF10 compared to Edarbi® tablets at pH 7.8 . 


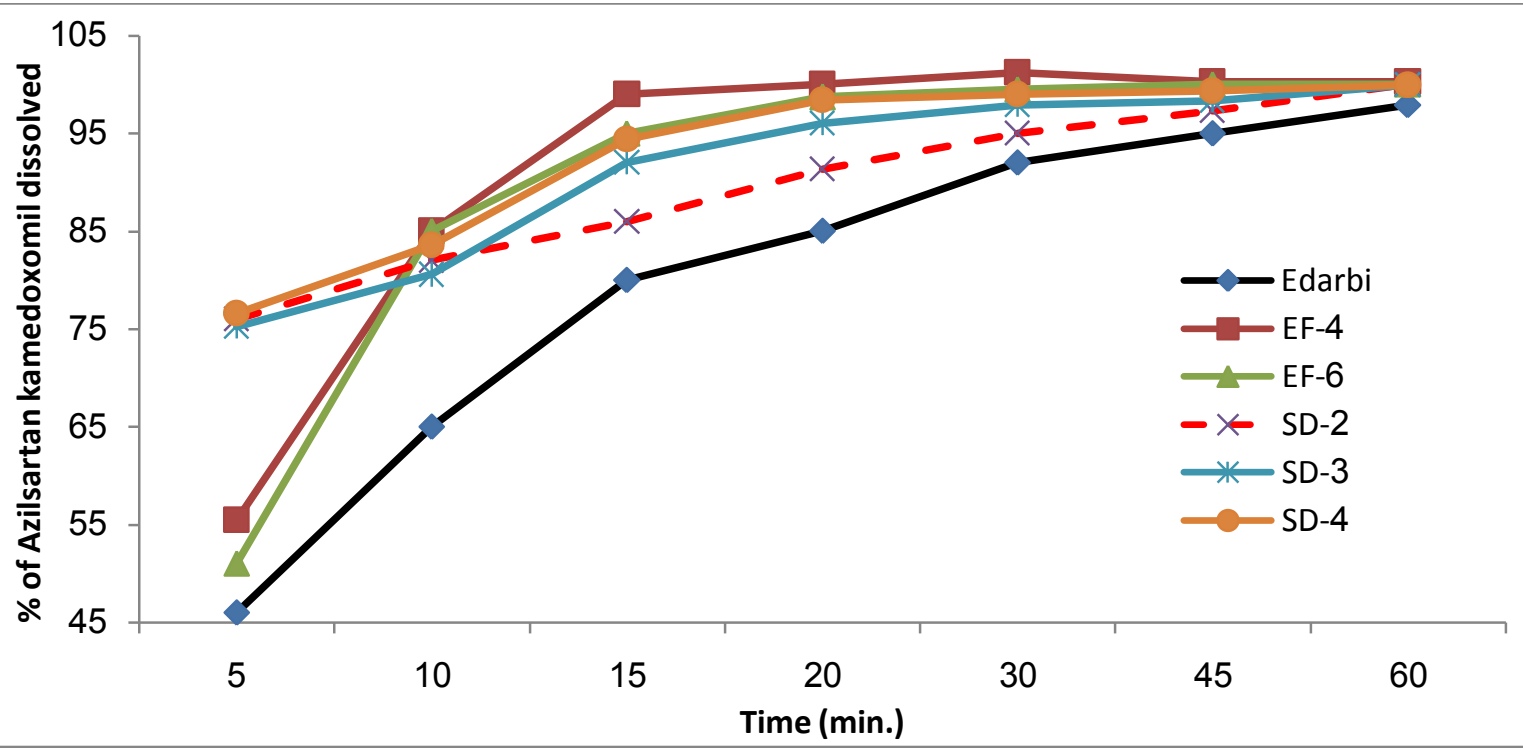

Fig.4:- Dissolution of selected azilsartan kamedoxomil formulation compared to Edarbi ${ }^{\circledR}$ tablets at $\mathrm{pH} 7.8$.

The expiration dates were found 71, 82, 76, 93 and 157 months for SD-2, SD-3, SD-4, EF-4 and EF-6, respectively All the tablets stored at $40^{\circ} \mathrm{C} \pm 2{ }^{\circ} \mathrm{C} / 75 \% \pm 5 \%$ RH showed significant decrease in hardness while an increase in the disintegration time. All formulae showed slight decrease in the dissolution rate compared to the values initial at 10 min dissolution time for formulae SD2, SD3, SD4, EF4 and EF6 and Edarbi ${ }^{\circledR}$ tablets, 1.2\%, 2\%, 2.55\%, 3\% and $2 \%$, respectively). The dissolution results show similarity between stored and fresh prepared tablets. The Physicochemical properties of the prepared tablets are present in table. 4

Table 4:- Physicochemical properties of the prepared tablets

\begin{tabular}{|c|c|c|c|c|c|c|c|c|}
\hline Formula & $\begin{array}{l}\text { Tablet } \\
\text { weight } \\
\text { (mg) }\end{array}$ & $\begin{array}{l}\text { Drug } \\
\text { content }(\%)\end{array}$ & $\begin{array}{l}\text { Disintegr } \\
\text {-ation } \\
\text { time } \\
\text { (sec.) }\end{array}$ & $\begin{array}{l}\text { Hardness } \\
\text { (Kp) }\end{array}$ & $\begin{array}{l}\text { Wetting } \\
\text { time (sec. } \pm \\
\text { S.D.) }\end{array}$ & $\begin{array}{l}\text { Water } \\
\text { absorption } \\
\text { ratio }(\%) \pm \\
\text { S.D }\end{array}$ & $\begin{array}{l}\text { In vitro } \\
\text { dispersion } \\
\text { time }(\text { sec.) }\end{array}$ & $\begin{array}{l}\text { Tablet } \\
\text { friability } \\
(\%)\end{array}$ \\
\hline Edarbi $\AA$ & $178 \pm 0.25$ & $99.758 \pm 0.54$ & $210 \pm 1.452$ & $9.2 \pm 0.08$ & $110 \pm 0.06$ & $56 \pm 0.31$ & $350 \pm 0.548$ & $0.173 \pm 0.05$ \\
\hline SD-1 & $170 \pm 0.15$ & $99.545 \pm 0.67$ & $50 \pm 0.123$ & $5.3 \pm 0.05$ & $7.05 \pm 0.35$ & $120 \pm 0.35$ & $80 \pm 0.323$ & $0.175 \pm 0.12$ \\
\hline SD-2 & $170 \pm 0.18$ & $99.320 \pm 0.75$ & $35 \pm 0.254$ & $5.6 \pm 0.26$ & $9.01 \pm 1.22$ & $86 \pm 1.22$ & $55 \pm 0.259$ & $0.062 \pm 0.29$ \\
\hline SD-3 & $170 \pm 0.37$ & $99.396 \pm 0.86$ & $40 \pm 0.315$ & $5.2 \pm 0.35$ & $7.14 \pm 0.07$ & $98 \pm 1.2$ & $70 \pm 0.336$ & $0.093 \pm 0.26$ \\
\hline SD-4 & $171 \pm 0.41$ & $98.924 \pm 0.89$ & $26 \pm 0.781$ & $5.8 \pm 0.09$ & $6.05 \pm 0.22$ & $111 \pm 0.23$ & $59 \pm 0.789$ & $0.175 \pm 0.34$ \\
\hline SD-5 & $171 \pm 0.25$ & $99.273 \pm 0.59$ & $35 \pm 0.079$ & $5.3 \pm 0.08$ & $9.12 \pm 0.14$ & $97 \pm 0.14$ & $66 \pm 0.167$ & $0.071 \pm 0.19$ \\
\hline SD-6 & $170 \pm 0.41$ & $98.969 \pm 0.64$ & $53 \pm 0.226$ & $5.9 \pm 0.12$ & $7.32 \pm 0.11$ & $85 \pm 0.51$ & $73 \pm 0.226$ & $0.164 \pm 0.19$ \\
\hline SD-7 & $172 \pm 0.43$ & $98.985 \pm 0.86$ & $38 \pm 0.149$ & $4.3 \pm 0.15$ & $8.26 \pm 0.22$ & $103 \pm 0.36$ & $73 \pm 0.416$ & $0.225 \pm 0.34$ \\
\hline SD-8 & $171 \pm 0.27$ & $99.656 \pm 1.03$ & $40 \pm 0.108$ & $5.1 \pm 0.11$ & $9.51 \pm 0.12$ & $110 \pm 0.12$ & $80 \pm 0.206$ & $0.139 \pm 0.10$ \\
\hline SD-9 & $172 \pm 0.14$ & $99.867 \pm 1.56$ & $53 \pm 0.225$ & $6.1 \pm 0.21$ & $8.09 \pm 0.207$ & $92 \pm 0.27$ & $90 \pm 0.292$ & $0.079 \pm 0.36$ \\
\hline SD 10 & $171 \pm 0.38$ & $99.883 \pm 0.95$ & $46 \pm 0.125$ & $5.3 \pm 0.07$ & $10.12 \pm 0.06$ & $120 \pm 0.63$ & $79 \pm 0.230$ & $0.099 \pm 0.18$ \\
\hline SD-11 & $170 \pm 0.25$ & $98.969 \pm 0.75$ & $53 \pm 0.221$ & $5.2 \pm 0.22$ & $11.36 \pm 0.15$ & $99 \pm 1.1$ & $93 \pm 0.296$ & $0.079 \pm 0.11$ \\
\hline SD 12 & $171 \pm 0.34$ & $98.985 \pm 0.89$ & $48 \pm 0.141$ & $5.9 \pm 0.1$ & $9.63 \pm 0.14$ & $120 \pm 0.24$ & $78 \pm 0.141$ & $0.082 \pm 0.20$ \\
\hline EF-1 & $180 \pm 0.33$ & $99.794 \pm 1.03$ & $55 \pm 0.207$ & $5.6 \pm 0.26$ & $7.35 \pm 0.326$ & $103 \pm 0.36$ & $86 \pm 0.682$ & $0.042 \pm 0.31$ \\
\hline EF-2 & $181 \pm 0.46$ & $99.897 \pm 1.56$ & $53 \pm 0.125$ & $5.2 \pm 0.35$ & $6.78 \pm 0.078$ & $87 \pm 0.49$ & $110 \pm 0.496$ & $0.196 \pm 0.27$ \\
\hline
\end{tabular}




\begin{tabular}{|l|l|l|l|l|l|l|l|l|}
\hline EF-3 & $180 \pm 0.24$ & $99.894 \pm 0.95$ & $50 \pm 0.108$ & $5.8 \pm 0.09$ & $9.05 \pm 0.196$ & $92 \pm 0.27$ & $132 \pm 0.246$ & $0.196 \pm 0.36$ \\
\hline EF-4 & $180 \pm 0.31$ & $99.642 \% \pm 1.09$ & $52 \pm 0.225$ & $5.9 \pm 0.08$ & $8.11 \pm 0.248$ & $110 \pm 0.63$ & $80 \pm 0.496$ & $0.171 \pm 0.19$ \\
\hline EF-5 & $182 \pm 0.16$ & $98.672 \pm 0.68$ & $42 \pm 0.108$ & $5.9 \pm 0.14$ & $8.19 \pm 0.108$ & $78 \pm 0.14$ & $120 \pm 0.236$ & $0.179 \pm 0.19$ \\
\hline EF-6 & $180 \pm 0.13$ & $98.967 \pm 0.89$ & $40 \pm 0.225$ & $6.1 \pm 0.16$ & $7.26 \pm 0.317$ & $85 \pm 0.51$ & $140 \pm 0.325$ & $0.259 \pm 0.29$ \\
\hline EF-7 & $180 \pm 0.33$ & $99.764 \pm 1.09$ & $49 \pm 0.108$ & $5.9 \pm 0.08$ & $7.51 \pm 0.125$ & $95 \pm 0.64$ & $72 \pm 0.493$ & $0.225 \pm 0.12$ \\
\hline EF-8 & $181 \pm 0.40$ & $99.847 \pm 0.98$ & $65 \pm 0.225$ & $6.9 \pm 0.16$ & $8.11 \pm 0.230$ & $103 \pm 0.19$ & $141 \pm 0.340$ & $0.092 \pm 0.34$ \\
\hline EF-9 & $180 \pm 0.46$ & $99.279 \pm 1.03$ & $46 \pm 0.108$ & $5.8 \pm 0.09$ & $10.11 \pm 0.352$ & $92 \pm 0.27$ & $120 \pm 0.640$ & $0.146 \pm 0.39$ \\
\hline EF-10 & $180 \pm 0.26$ & $98.892 \pm 1.56$ & $45 \pm 0.225$ & $5.6 \pm 0.17$ & $9.16 \pm 0.462$ & $103 \pm 0.12$ & $110 \pm 0.241$ & $0.195 \pm 0.30$ \\
\hline
\end{tabular}

None of the tablets stored at $40^{\circ} \mathrm{C} \pm 2{ }^{\circ} \mathrm{C} / 75 \% \pm 5 \% \mathrm{RH}, 30^{\circ} \mathrm{C} \pm 2{ }^{\circ} \mathrm{C} / 65 \% \pm 5 \% \mathrm{RH}$ and $25^{\circ} \mathrm{C} \pm 2^{\circ} \mathrm{C} / 60 \% \pm 5 \% \mathrm{RH}$ showed any changes in the colour or appearance throughout the storage period except SD-2 which shows very pale yellow colour when stored in transparent strips at $40^{\circ} \mathrm{C} \pm 2{ }^{\circ} \mathrm{C} / 75 \% \pm 5 \% \mathrm{RH}$

Fig. 5:- illustrates the In plot of $\mathrm{K}$ (degradation rate constant) of the prepared formulae at different temperatures. The expiration times were determined by extrapolation of Arrhenius curve

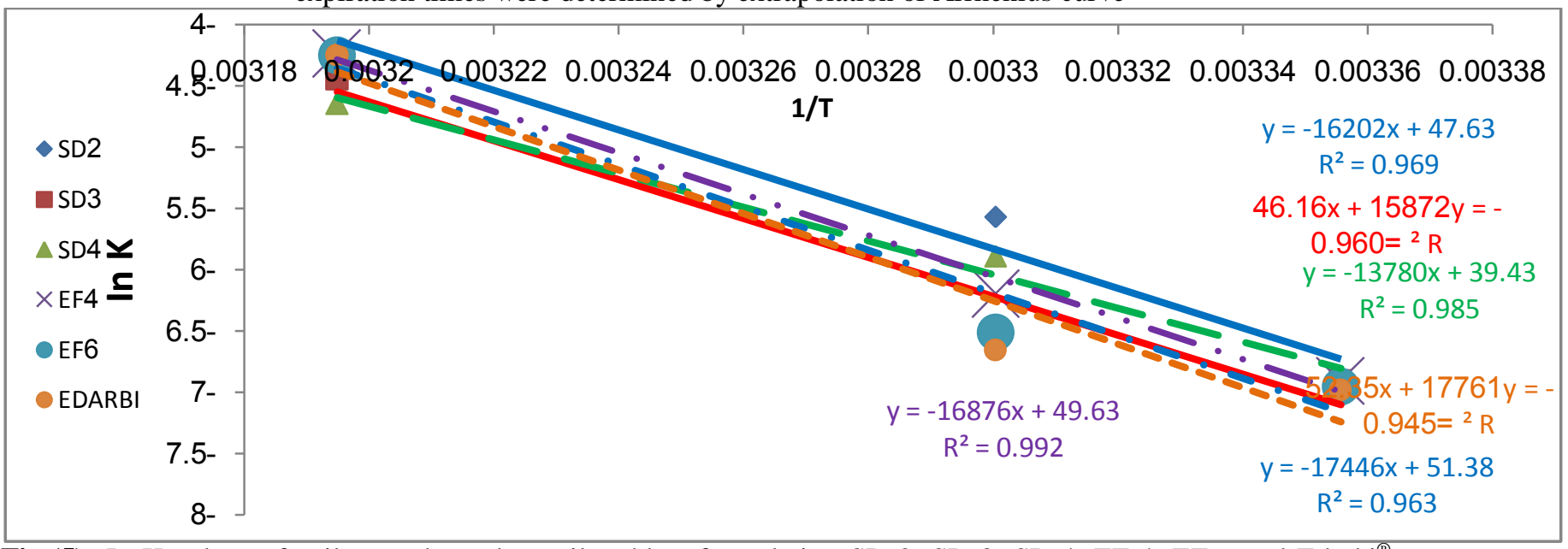

Fig.(5): In $\mathrm{K}$ values of azilsartan kamedoxomil tablets formulation SD-2, SD-3, SD-4, EF-4, EF-6 and Edarbi ${ }^{\circledR}$ 40mg tablets stored for twelve weeks

Results of hardness of prepared formulation and Edarbi ${ }^{\circledR} 40 \mathrm{mg}$ tablets showing decrease in hardness after storage $40^{\circ} \mathrm{C} \pm 2{ }^{\circ} \mathrm{C} / 75 \% \pm 5 \% \mathrm{RH}$ are shown in Fig. 6 .

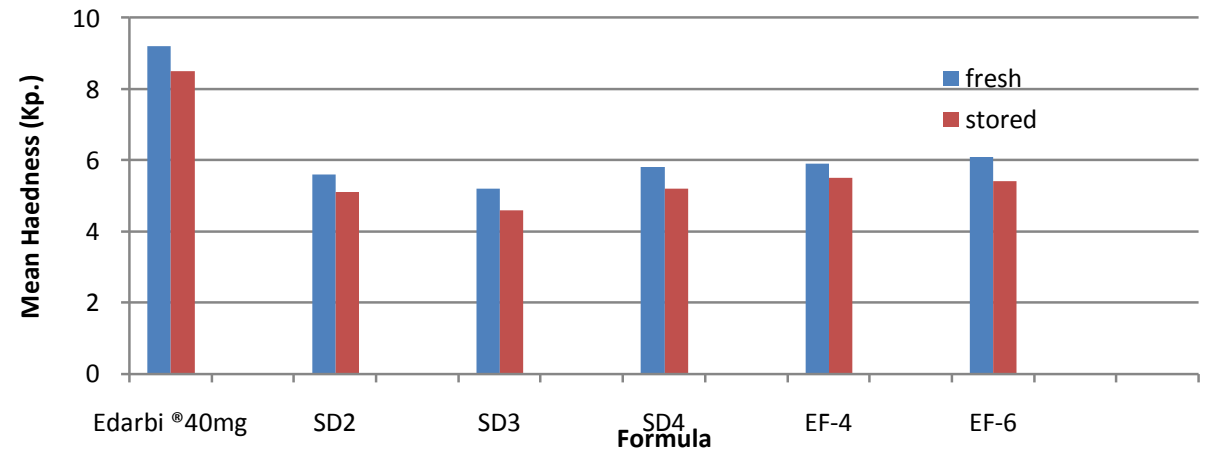

Fig.6:- Effect of storage on the hardness of tablets formulations SD2, SD3, SD4, EF4, EF-6 and Edarbi ${ }^{\circledR}$ tablets. 
Results of disintegration time of prepared formulation and Edarbi ${ }^{\circledR} 40 \mathrm{mg}$ tablets showing increase in disintegration time after storage $40^{\circ} \mathrm{C} \pm 2{ }^{\circ} \mathrm{C} / 75 \% \pm 5 \%$ RH are shown in Fig. 7.

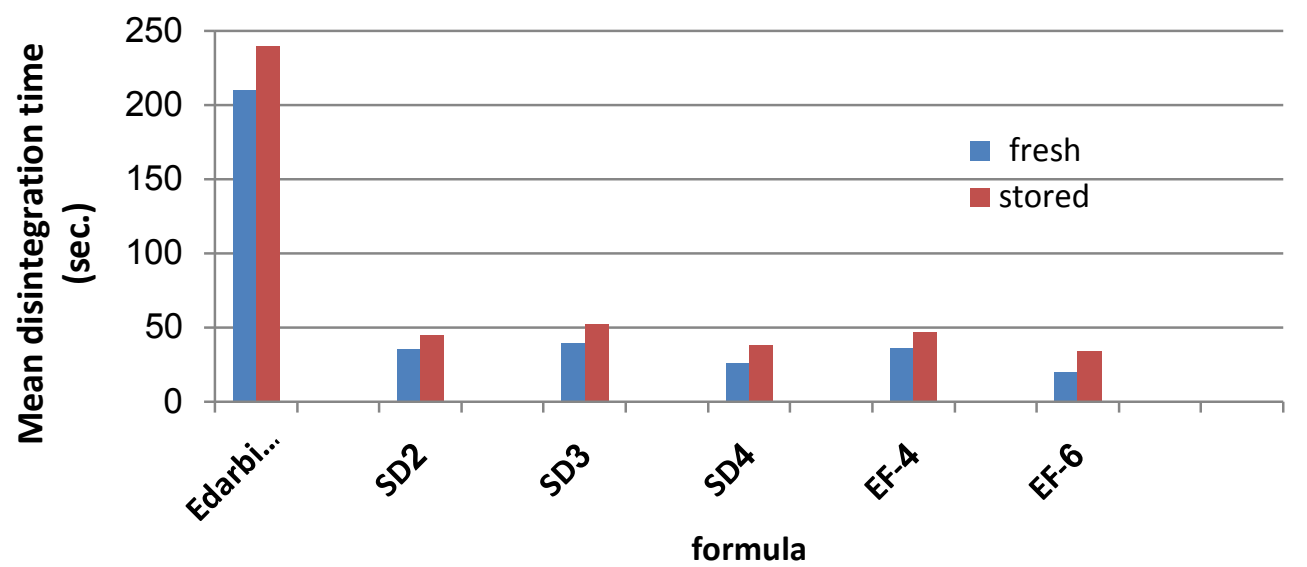

Fig.7:- Effect of storage on the disintegration time of tablets formulations SD2, SD3, SD4, EF4, EF-6 and Edarbi ${ }^{\circledR}$ tablets.

Results of wetting time of prepared formulation and Edarbi ${ }^{\circledR} 40 \mathrm{mg}$ tablets showing increase in wetting time after storage $40^{\circ} \mathrm{C} \pm 2^{\circ} \mathrm{C} / 75 \% \pm 5 \% \mathrm{RH}$ are shown in Fig. 8 .

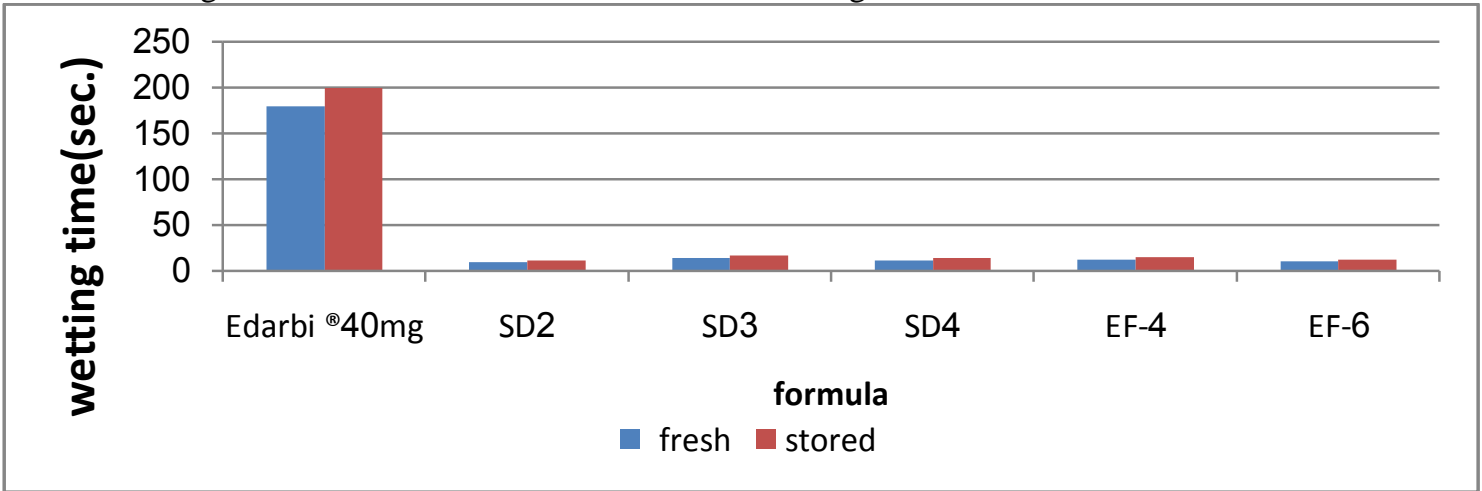

Fig.8:- Effect of storage on the wetting time of tablets formulations SD2, SD3, SD4, EF4, EF-6 and Edarbi ${ }^{\circledR}$ tablets.

Results of water absorption ratio of prepared formulation and Edarbi ${ }^{\circledR} 40 \mathrm{mg}$ tablets showing decrease in water absorption ratio after storage $40^{\circ} \mathrm{C} \pm 2{ }^{\circ} \mathrm{C} / 75 \% \pm 5 \% \mathrm{RH}$ are shown in Fig. 9 .

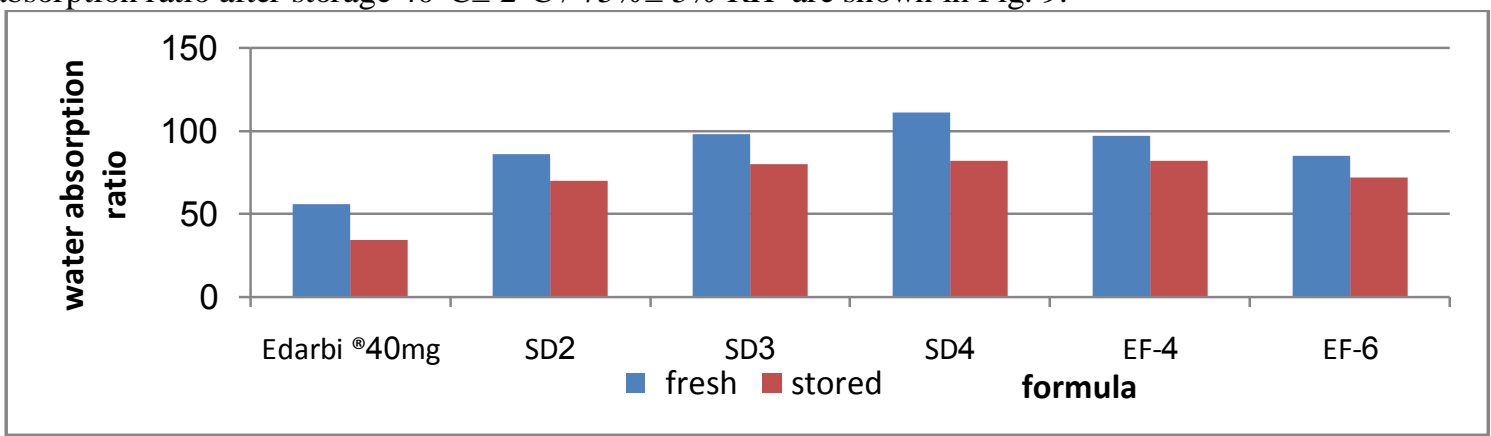

Fig.9:- Effect of storage on the water absorption ratio of tablets formulations SD2, SD3, SD4, EF4, EF-6 and Edarbi ${ }^{\circledR}$ tablets.

The dissolution rate of all azilsartan kamedoxomil selected tablets formulae (SD2, SD3, SD-4, EF-4 and EF-6) was decreased. However, when similarity factor for all formulae fresh and stored was employed, the results indicate similarity between the fresh and stored tablets. 


\section{References:-}

1. Jones, D. J., Jackson, H.S., Agboton, C. and Martin, S.T.; Azilsartan Medoxomil (Edarbi) The eighth angiotensin II receptor blocker, Pubpubmed Med Central® journal); 36(10): 634-636, 638-640. (2011)

2. Center for Drug Evaluation and Research. Azilsartan medoxomil Clinical Pharmacology and Biopharmaceutics Review. http://www.accessdata. fda.gov/drugsatfda_docs/nda/2011/200796Orig1s000ClinPharmR.pdf

3. Edarbi (azilsartan medoxomil) prescribing information. Takeda Pharmaceuticals America, Inc Deerfield, IL, USA, 2011. Available at:http://www.edarbi.com/

4. Ratnaparkhi, P.M, Mohanta, G.P and Upadhyay L.; Review on: Fast dissolving tablet. J. Pharm. Res.; 2(1): 512(2009)

5. Shukla D., Chakraborty S., Singh S., Mishra B.; Mouth Dissolving Tablets II: An Overview of Evaluation Techniques, Sci. Pharm. 77, p. 327-341 (2009)

6. Mohapatra, A., Parikh, R. and Gohel, M.; Formulation, development and evaluation of patient friendly dosage forms of metformin, Part-I: Orally disintegrating tablets: Asian J. Pharm.; 2, p. 167-171 (2008

7. Carr, R.L.; "Particle behavior, storage and flow", Br Chem. Eng., 15: 1541 (1970).

8. Li, Q., Rudolph, V., Weigl, B. and Earl, A.;"Interparticle van der Waals Force in Powder Flowability and Compactibility"; Int. J. Pharmceut., 280:77-93(2004)

9. Luner. P.E., Kirsch, .L.E., Majuru, S., Joshi, A.B., Wurster, D.E. and Redmon. M.P, Preformulation Studies on the S-Isomer of Oxybutynin Hydrochloride, an Improved Chemical Entity (ICE ${ }^{\mathrm{TM}}$ ), Drug Dev. Ind. Pharm., 27(4), 321-329 (2001).

10. " The British Pharmacopoeia", The Stationery Office, London: Electronic version (2014).

11. . "The Pharmacopoeia of United States of America", $35^{\text {th }}$ Ed., National Formulary 30, Mack publishing Co. Easton, vol. 2, Electronic version (2012).

12. Yunxia B, Hisakazu S, Yorinobu Y, Kazumi D, Akinobu O, Kotaro I. Preparation and evaluation of compressed tablet rapidly disintegrating in the oral cavity, Chem Pharm Bull, 44(11), 1996, 2121-127(1996).

13. Khinchi, P. M., Orally disintegrating tablets: A future prospectus., Int J Pharm Sci Bio., 71-79(2010)

14. Ashish, P., Mishra, P., Main, P., Harsoliya, M., \& Agrawal, S.. A review on-recent advancement in the development of rapid disintegrating tablet. Int J Life Sci Pharm Res, 1, 7-16(2011).

15. Martin, A., Bustamante, P., and Chun H.C.; in "Physiscal Pharmacy: Physical Chemical Principles in the Pharmaceutical Sciences", $4^{\text {th }}$ Ed., Philadelphia: Lea \& Febiger, p.289 (1993).

16. Karmarkar, B, Gonjari, I.D., Hosmani, A.H., Dhabale .P.N. and Bhise, S.B.;" Dissolution Rate Enhancement of Fenofibrate Using Liquisolid Tablet Technique, Part II; Evaluation of In Vitro Dissolution Profile Comparsion Methods" ; Lat. Am. J. Pharm., 28(4):538-543(2009)

17. Kamboj, M., Goyal, S., Rakha, P., Arora, G., Dureja, H. and Nagpal, M.; Formulation and Evaluation of Metformin Oro- Dispersible Tablets, Acta Poloniae Pharmaceutica ñ Drug Research; Vol. 68 No. 5 p. 717 $723(2011)$ 